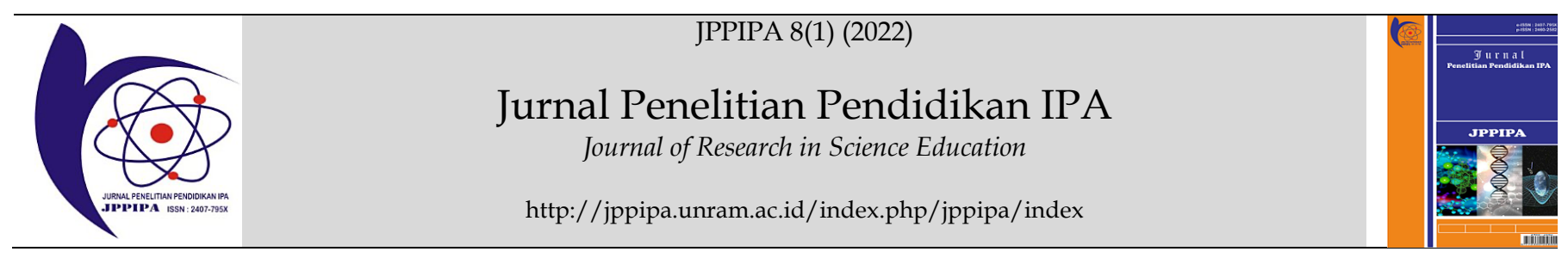

\title{
Development of Audiovisual-Based PowToon Animation Video on Chemical Bonds for Tenth Grade
}

\author{
Akmalia Mutiara Dewi ${ }^{1 *}$, Agus Kamaludin ${ }^{1}$ \\ ${ }^{1}$ Chemistry Education, State Islamic University of Sunan Kalijaga Yogyakarta, Yogyakarta, Indonesia.
}

DOI: $\underline{10.29303 / \text { jppipa.v8i1.865 }}$

\section{Article Info}

Received: August 8, 2021

Revised: January 10, 2022

Accepted: January 14, 2022

Published: January 31, 2022

\begin{abstract}
This research aimed to develop an audiovisual-based PowToon animation video on the subject matter of chemical bonds and analyze the quality of the audiovisual-based animated video as learning media to study chemical bonds based on the assessment of material experts, media experts, chemistry teachers, and students' responses. This research used development research methods (R\&D) with a 4D development model (Define, Design, Development, and Dissemination). However, the 4D development model was limited to the dissemination stage in this research. The product is an animated video, which is in the form of mp4, containing chemical bond materials. Based on product quality assessment by a material expert, it gained a percentage of $84.375 \%$ with very good (VG) category; from the media expert's assessment, it obtained a percentage of $96.428 \%$ with very good (VG) category; and according to assessment by chemistry teachers of high school, it got a percentage of $98.48 \%$ in the very good (VG) category. The product was responded to positively by students with a percentage of $95 \%$. Based on the results of assessments, the animated video can be used as an alternative media for the chemistry learning process in the classroom.
\end{abstract}

Keywords: Research Development; Animation Video; PowToon; Chemical Bond.

Citation: $\quad$ Dewi, A. M., \& Kamaludin, A. (2022). Development of Audiovisual-Based PowToon Animation Video on Chemical Bonds for Tenth Grade. Jurnal Penelitian Pendidikan IPA, 8(1), 222-229. https://doi.org/10.29303/jppipa.v8i1.865

\section{Introduction}

Technology and education are like two sides of the same coin that cannot be separated (Maswan \& Muslimin, 2017). This is proven that in the era of industrial revolution 4.0, the world of education is more dependent on technological development (Deliviana, 2017). However, the problem that often appears in the world of education is that the use of technology to improve the learning quality is not yet optimal (Widyawati, 2019).

The use of technology and information in term of improving the learning quality can be done by using computer and internet network (Cholik, 2017). The use of computer in the learning process serves to improve the quality of learning (Sudarsana, et al., 2018). A teacher, in the learning process, is required to be able to use computer to carry out some innovations that are corresponding with the current dynamics of science and technology (Asmaningrum, 2018). However, according to the research by Suharwoto, only $40 \%$ of teacher without using technology (who do not teach ICT) is ready for the use of technology (Maharani, 2018).

An effort that can be made to get teacher ready for technology is IT training (Riskiawan, et al., 2016). Through this activity, teachers can improve their skills in order to be able to create information technologybased learning media (Maharani \& Luthfi, 2016). However, the use of media as learning resources is still limited to using PowerPoint, whereas the use of PowerPoint has a weakness that can make students tend not to pay attention (Pardany \& Dewi, 2020).

Learning media is a medium which is made by teacher creatively and innovatively and it is used to deliver the subject matter in order that students do not feel bored when taking lessons in the classroom (Ayu, et al., 2019). One of the innovative products, the learning

\footnotetext{
*Email: aguskamaludin@gmail.com
} 
media that can meet the needs of various students is animation. PowToon is a learning media in the form of animated video with features of handwriting animation, animated cartoon, and livelier transition effect. Based on the research conducted by Ayu, et al. (2019), it is stated that students' responses to the use of PowToon animation video as learning media on science subjects received a percentage of $89.5 \%$ and it was regarded as the appropriate category. Students were more interested and easier to understand the materials presented through the video which was designed attractively and favorably. This is confirmed by the research conducted by Swank (2011) which states that students' effectiveness to absorb the lesson was $40 \%$ through visual stimulus, $25 \%$ of auditory stimulus, $17 \%$ of tactile stimulus, $15 \%$ of organic sensation, and 3\% of aroma and taste. Based on this research, it can be concluded that the students' acceptance of information for is influenced by sight (visual) and hearing (auditory). Based on the interviews with several students at SMA Negeri 1 of Serang City, when students do not understand chemistry, they tend to learn through videos from YouTube. This is because there is animation in the videos that students are pleasure to study.

Chemistry is a science that studies matter and its changes (Chang, 2004). One of the chemistry materials taught in high school is chemical bond. Chemical bond is a basic concept to be understood by students correctly, so that students do not experience difficulties in studying the further materials such as compound nomenclatures, compound properties, molecular forms, and others (Openhotman, et al., 2017). The subject matter of chemical bond is a quite difficult subject to be studied. Based on interviews with some chemistry teachers in Serang City, one of difficult subjects to be explained in tenth grade is chemical bond because it is invisible (abstract); symptoms caused by chemical bond cannot be obtained from experiments in the ordinary chemistry laboratory; the occurrence of chemical bond must be studied theoretically; and the application of chemical bond theory requires reasoning ability to work on it (Apriyanti, 2010).

Several development researches have been carried out including research conducted by Latifah \& Lazulva (2020) which produced PowToon animation video on the periodic system of elements. Through the research, the product was regarded practical by chemistry teachers and students at school. Respectively, it gained the percentage of $86.87 \%$ and $90 \%$ with the very effective category. In addition, the research by Awalia, et al. (2019) which produced PowToon animation as learning media to study mathematics stated that PowToon animation as learning media could help students of fourth grade understand mathematics materials. Therefore, interactive learning media which is in the form of animated video of PowToon that can give reasoning stimulus needs to be developed.

The development of audiovisual-based PowToon animation video on chemical bond for tenth grade is expected to make it easier for teachers to simplify the content of the materials; make the materials more concrete, simple, and attractive; and increase students' enthusiasm to study.

\section{Method}

The research used research and development (R\&D) as the method. The development model used is 4D development which consists of four stages (define, design, develop, and disseminate). However, this research was limited into the development stage only. The 4D model was chosen because this research aimed to develop a product which was in the form of audiovisual-based PowToon as learning media. Furthermore, the explanation is as follows: The definition stage was used to determine and define the requirements needed for the development. The definition stage includes five main steps. First, in the front-end analysis, interview was conducted with chemistry teachers to find out the learning process in the classroom and the learning media being used. Second, in the student analysis, interview was conducted towards high school students. The interview discussed about problems being faced during learning chemistry at school. Third, in the concept analysis, core competencies, basic competencies, and learning resources were analyzed. Fourth, in the task analysis, core competencies and basic competencies were elaborated into learning indicators. Fifth, the objectives of learning were formulated.

The design stage was carried out to create the design of learning media. The design stage includes 5 stages. The first stage is media selection. The media selection being used in the research was adjusted to the characteristics of students and the materials in order to achieve the competencies that had been formulated. The second is format selection. The format selection to be used in the learning media included: title, learning objectives, appreciation, materials, and evaluation. The third is reference collection. The materials which was made and developed was chemical bond materials. Fourth, an initial design was created. Here, the initial design involves the design of all learning devices to be done before the test is carried out. Fifth, instrument production was conducted by making product quality instrument and product implementation test.

The development stage serves to produce the final format of learning media. The development stage has 4 stages. The first stage is product manufacture. The product manufacture was adjusted to the initial design at the design stage. The developed product was then consulted with the supervisor before being validated by 
expert lecturer. The second stage is expert validation. The validation was carried out by media expert and material expert. The validation of the developed product by the experts was intended to obtain suggestions and input. The third stage is revision. The product that has been validated and asked for advices to peer reviewers were then revised according to the input and suggestions before being assessed by the chemistry teachers and responded by students. The fourth stage is product assessment. The product assessment was carried out through a limited field test towards three chemistry teachers and being responded by 10 students. The result of limited test served to improve the product. The research subjects were students of class X MIPA at SMA N 1 Serang City. The design of test which was carried out consisted of a limited test to 10 students. The limited test aimed to find out students' responses. This research was conducted for 5 months starting from December 2020 to May 2021.

The data of product validation which is in the form of input from peer reviewers, media expert, material expert, and reviewer is in the form of qualitative data. The qualitative data was then converted into quantitative data based on the Likert scale. It can be seen in Table 1.

Table 1. The rules of scoring

\begin{tabular}{|c|c|}
\hline Description & Score \\
\hline VG (Very Good) & 4 \\
\hline G (Good) & 3 \\
\hline P (Poor) & 2 \\
\hline VP (Very Poor) & 1 \\
\hline
\end{tabular}

Furthermore, the validation score was calculated by using the following equation:

$$
\bar{X}=\frac{\sum x}{n}
$$

Description:

$$
\begin{array}{ll}
\overline{\mathrm{X}} & =\text { Average score } \\
\Sigma \mathrm{X} & =\text { Total score from each assessor } \\
\mathrm{n} & =\text { Number of assessors }
\end{array}
$$

Furthermore, the score aspect was modified by using assessment criterion of a four-point scale. The reference for converting the score into a four-point scale is as follows in table 2.

Table 2. The assessment criteria

\begin{tabular}{lll}
$\begin{array}{l}\text { Range of Score (i) } \\
\text { Quantitative }\end{array}$ & Value & Qualitative Category \\
\hline $\mathrm{X} \geq \overline{\mathrm{X}}_{\mathrm{i}+1 . S B x}$ & $\mathrm{~A}$ & VG (Very Good) \\
$\overline{\mathrm{X}}_{+1 . S B x}>\mathrm{X} \geq \overline{\mathrm{X}}_{\mathrm{i}}$ & $\mathrm{B}$ & $\mathrm{G}($ Good) \\
$\overline{\mathrm{X}}_{\mathrm{i}}>\mathrm{X} \geq \overline{\mathrm{X}}_{\mathrm{i}-1 . \mathrm{SBx}}$ & $\mathrm{C}$ & $\mathrm{P}($ Poor) \\
$\mathrm{X}<\overline{\mathrm{X}}_{\mathrm{i}-1 . \mathrm{SBx}}$ & $\mathrm{D}$ & $\mathrm{VP}$ (Very Poor) \\
\hline
\end{tabular}

Description:

$$
\begin{aligned}
& \mathrm{X}=\text { Score achieved } \\
& \overline{\mathrm{X}}_{\mathrm{i}}=\text { Average of ideal score }(1 / 2 \text { (ideal maximum } \\
& \text { score }+ \text { ideal minimum score) } \\
& \mathrm{SBx}=\text { Ideal standard deviation }(1 / 6 \text { (ideal maximum } \\
& \text { score }- \text { ideal minimum score) } \\
& \text { Ideal maximum score } \quad=\text { criterion item } \times \text { higest score } \\
& \text { Ideal minimum score } \quad=\text { criterion item } \times \text { lowest score }
\end{aligned}
$$

Students' response data was converted into quantitative data by using the Guttman scale (Sugiyono, 2011). The determination of the Guttman scale can be seen in table 3.

Table 3. The rules of determining Guttman scale

\begin{tabular}{ll}
\hline Description & Score \\
\hline Yes & 1 \\
No & 0 \\
\hline
\end{tabular}

After that, the percentage of the ideal product and each aspect were calculated as a whole by the formula:

Ideal Percentage $=\frac{\text { Achieved score }}{\text { Ideal maximum score }} \chi 100 \% \ldots \ldots$

\section{Result and Discussion}

The chosen media in this development research is an animated video of PowToon. PowToon is chosen because it is a web-based animation software that the user does not need to download. Powtoon also has several features which are provided for free so that the user can use it right away. Animation is used as a learning medium because it can attract students' attention; strengthen students' motivation and ability to explain change of state any time (Farizi, et al., 2019). Video is one type of media that combines audio and visual. The ability of video to describe vivid images and sound becomes its own charm. Video can also present the information; explain the processes; and elaborate the complex concepts (Arsyad, 2011). The advantages of using learning media in the form of animated video of PowToon have been explained by Swank (2011). Swank (2011) stated that students' effectiveness to absorb learning materials is $40 \%$ through visual stimulus, $25 \%$ of auditory stimulus, $17 \%$ of tactile stimulus, $15 \%$ of organic sensation, and 3\% of aroma and taste. Based on the research by Swank (2011) it can be concluded that the students' acceptance for information is influenced by sight (visual) and hearing (audio). The approach used in this research is $4 \mathrm{D}$.

\section{Definition Stage}

The definition stage has five major steps. Those are the front-end analysis, student analysis, concept analysis, task analysis, and specification of learning objectives. The front-end analysis was conducted by 
interviewing several chemistry teachers at SMA N 1 Serang City, SMA N 3 Serang City, and SMA Peradaban Serang. The topic being discussed was associated to learning chemistry in the classroom and the use of learning media. Furthermore, student analysis was conducted on students of class X MIPA at SMA N 1 Serang City. Based on the interview, students tend to like learning by using media in the form of video. This is because there are animations in the video that students are pleasure to study. Furthermore, in the concept analysis, core competencies, basic competencies, and learning resources were analyzed. In the task analysis, the core competencies and basic competencies were elaborated into learning indicators. Hereafter, the learning objectives are formulated.

\section{Design Stage}

At the design stage, there are 5 stages. They are media selection, design selection, reference collection, creating the initial design, and instrument manufacture.
Media being selected in this research was PowToon. Furthermore, at design selection, design of the display was made by using Canva which was either downloaded it from Google or it is already available in PowToon. In reference collection, the materials to be included in this medium was chemical bond consisting of several sub materials, namely, definition of chemical bond, stability of element, Lewis's structure, ionic bond, covalent bond, and coordinate covalent bond. The materials being used to create video as learning media were only up to the coordinate covalent bond due to the limited time that the researcher has. Hereafter, the initial design was created. During creating animated video of PowToon as learning media, other supporting software were used, namely, Camtasia 2019, Audacity, and Canva. The following is the process of making animated video of PowToon.

The first is a brief summary of the chemical bond materials that will be presented in the video. Second, the product is created by using PowToon.
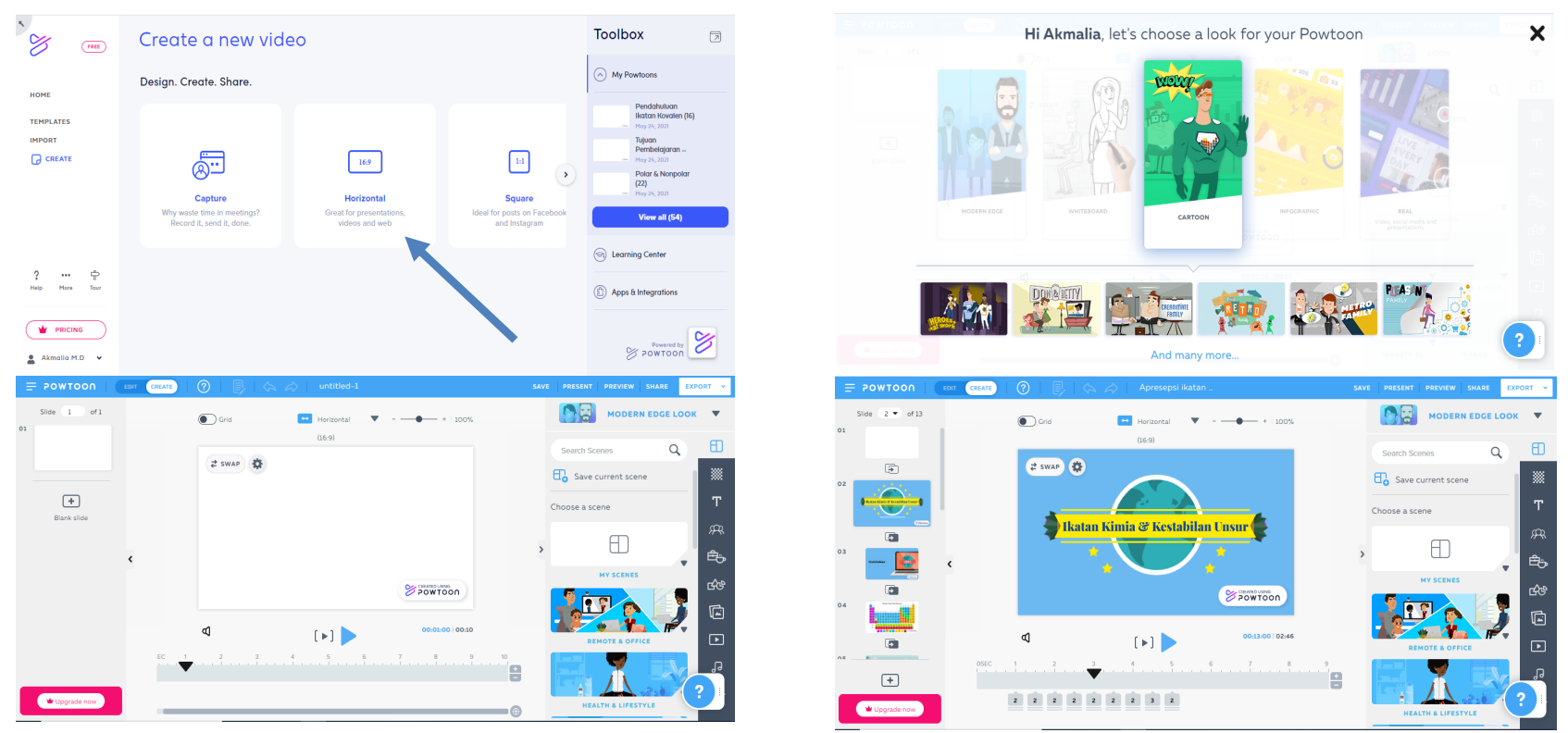

Figure 1. The process of video production in PowToon

After creating video by using PowToon, then the screen recording was conducted by using the Camtasia 2019 application. Camtasia 2019 was used to record activities on the computer desktop according to the user's wishes.

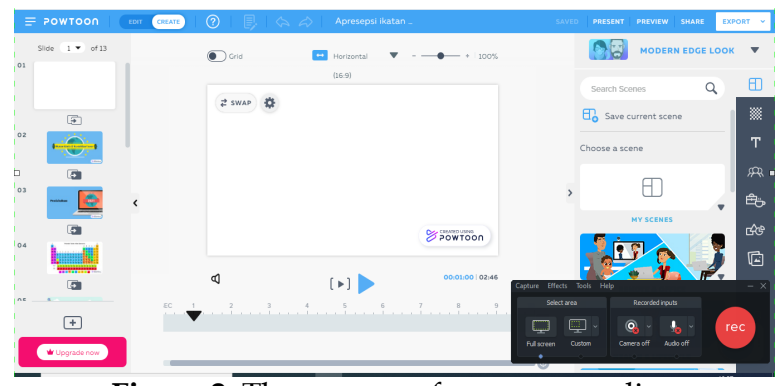

Figure 2. The process of screen recording
Furthermore, the result of screen recording was edited by using Camtasia 2019. In this editing process, user can add sound, music, cutting videos, and so on.

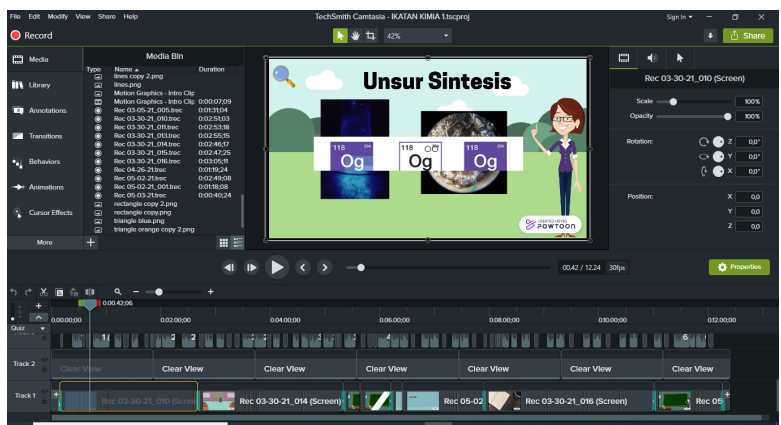

Figure 3. The process of video editing from the screen 
recorder by using Camtasia 2019

Sound editing is conducted by using the audacity application so that the sound produced has good quality.

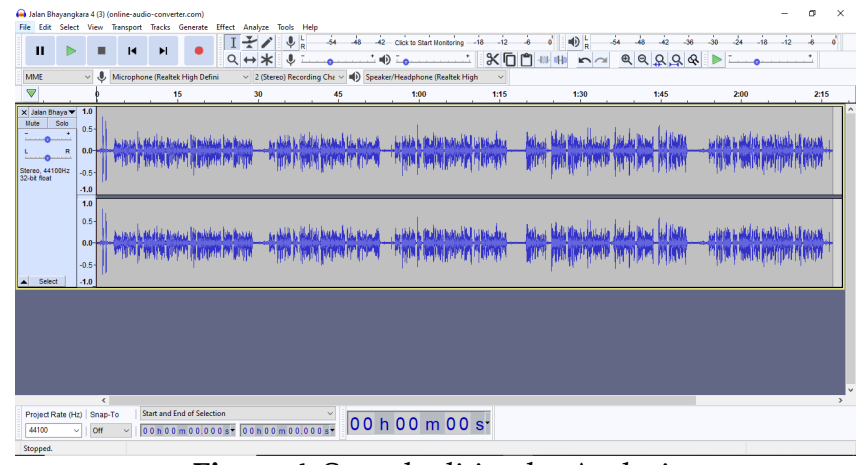

Figure 4. Sound editing by Audacity

The final product includes six videos with a duration of $10-20$ minutes per video. The opening section consists of the title, author's name, appreciation, and learning objectives.

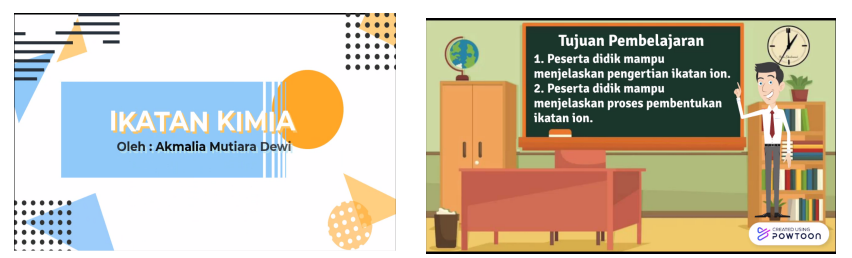

Figure 5. Video's opening section

The content section includes learning materials.

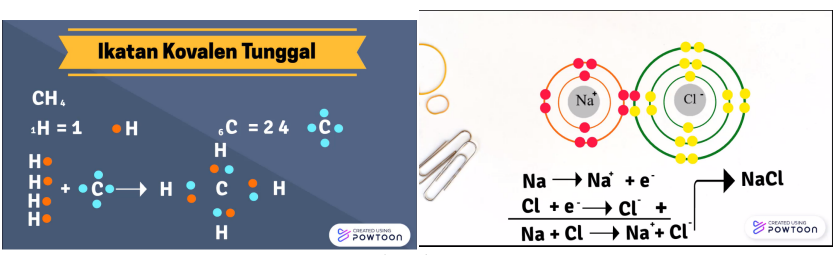

Figure 6. Video's content section

The closing section provides exercises.

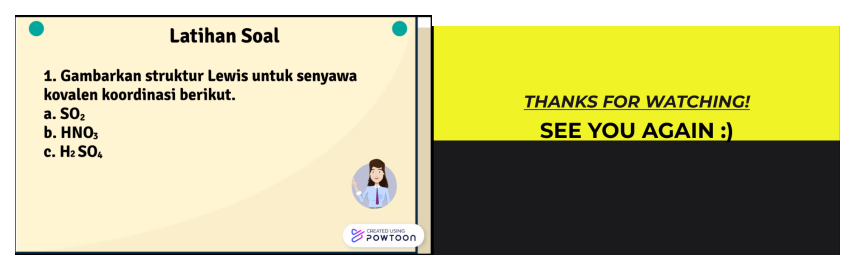

Figure 7. Video's closing section

Furthermore, the instrument was created by making questionnaire in the form of a Likert scale and students' response sheets in the form of a Guttman scale. The questionnaire contained several aspects that would be assessed by expert lecturer and teachers. Whereas, the students' responses were only statements that would be answered by the students with a yes or no answer. The instrument that has been created was consulted first with the supervisor before it was validated. Instrument validation was carried out by one instrument expert lecturer.

\section{Development stage}

After manufacturing the product, the product was then validated by experts. The experts were media expert and material expert. The following are the results of validation from media expert lecturer and material expert.

Media expert played a role in validating media in terms of readability, audiovisual appearance, and product characteristics. The feasibility test was carried out by media expert from UIN Sunan Kalijaga Yogyakarta. The following are the results of quality assessment analysis of audiovisual-based PowToon animation video according to media expert lecturer. It can be seen in Table 1.

Table 1. The results of quality analysis of audiovisualbased PowToon animation video according to media expert

\begin{tabular}{lll}
\hline Assessment Aspect & $\begin{array}{l}\text { Ideal } \\
\text { Percentage }\end{array}$ & Category \\
\hline Readability & $91.67 \%$ & VG \\
Audi-visual display & $100 \%$ & VG \\
Product characteristics & $100 \%$ & VG \\
\hline
\end{tabular}

Overall, the result of the assessment of audiovisualbased PowToon animation video has a total score of 27 with an ideal percentage of $96.42 \%$. Based on the assessment criteria by media expert lecturer, the achieved total score/score shows that $(X)=27$ is in the range of $X \geq 21$ and it is considered as the very good (VG) category. This is in line with the research conducted by Meianti (2018) in which feasibility result was claimed as very feasible category. Therefore, the developed product can be used as learning media.

Material expert played a role to validate media in terms of language, material, presentation, and product characteristics. The test of media feasibility was conducted by a material expert from UIN Sunan Kalijaga Yogyakarta, namely Mrs. Laili Nailul Muna, M.Sc. based on result of quality assessment analysis of audiovisualbased PowToon animation video. It can be seen in Table 2.

Table 2. The result of quality assessment analysis of audiovisual-based PowToon animation video by material expert

\begin{tabular}{lll}
\hline Assessment Aspect & Ideal Percentage & Category \\
\hline Language & $83.33 \%$ & VG \\
Material & $91.67 \%$ & VG \\
Presentation & $75 \%$ & VG \\
Product Characteristics & $75 \%$ & VG \\
\hline
\end{tabular}


Overall, material assessment of audiovisual-based PowToon animation video gains a total score of 27 with ideal percentage of $84.375 \%$. Based on the assessment criteria by expert lecturer, the achieved total score/score shows $(X)=27$ is in the range of $X \geq 24$ and it is regarded as the very good (VG) category. This is in line with research conducted by Arianti \& Sulisworo (2019) in which the material feasibility was claimed as the very feasible category. Therefore, the product can be used as media in the learning process.

Based on the validation by material expert and media expert above, the average of validators' assessments shows very good results. This shows that the quality of the PowToon animation video as learning media that has been developed has met the pedagogic element. It can be claimed as good learning media and it is appropriate to be used by the target user, namely students. However, there are some comments and suggestions from the validators for revision so that the developed product, audiovisual-based PowToon animation video, becomes a better product. The product revision involves coloring electron in each atom, adding a negative charge in electron, and lowering the position of number 16 on atom $S$ in order to reflect the atomic number. Whereas, the material expert lecturer did not have suggestions and input on this developed product.

The animated video of PowToon that has been validated and revised according to comments and suggestions from experts was then tested through chemistry teachers to find out how practical it was. The teacher's role was to assess the media in terms of language, material, presentation, audiovisual display, and product characteristics. The product assessment was conducted by three chemistry teachers of high school from SMA N 1 of Serang City, SMA N 3 of Serang City, SMA Peradaban of Serang. The following is the result of quality assessment analysis of audiovisualbased PowToon animation video according to the high school chemistry teachers

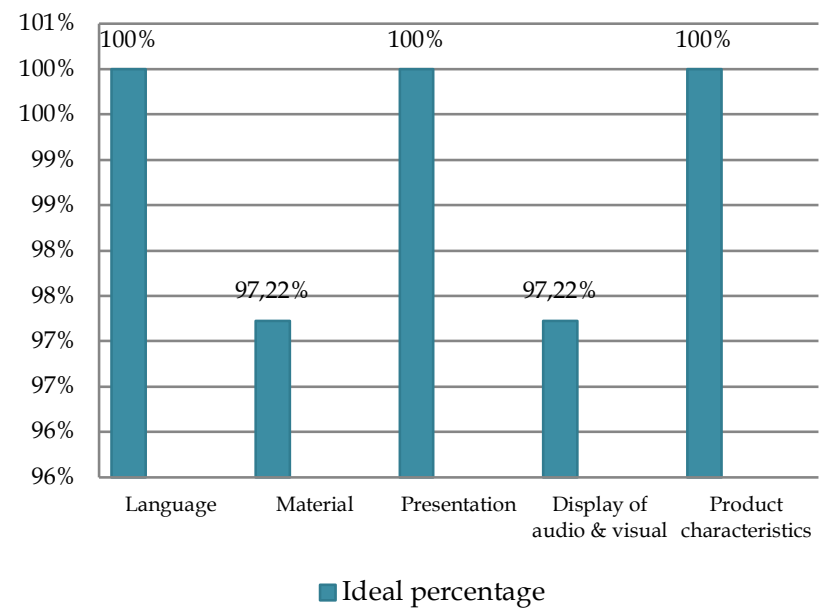

Figure 8. Assessment data of high school chemistry teachers

Overall, based on the assessment conducted by chemistry teachers, the product gains an average score of 43.33 with ideal percentage of $98.48 \%$. Based on the assessment criteria by chemistry teachers, the average score of $=43.33$ is in the range of $X \geq 33$ and it is regarded as the very good (VG) category.

The next stage is conducting a limited test toward 10 students. Students' responses played a role in assessing the media in terms of language, material, presentation, audio and visual display, and product characteristics. Students' responses were gained through tenth grade students of SMA N 1 Serang City. The following is the data of students' responses to audiovisual-based PowToon animation video.

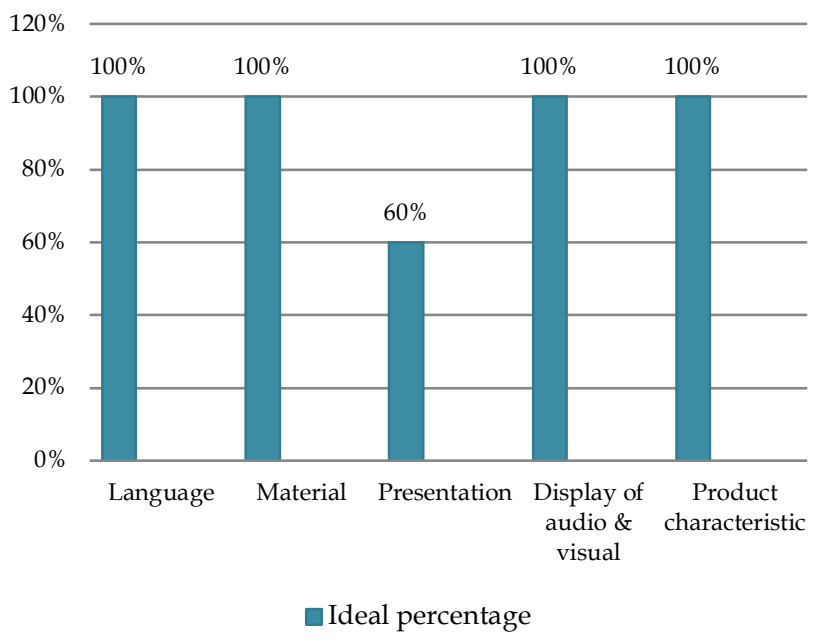

Figure 9. Data of student's response

The response which has been generated through 10 students is $95 \%$ with a score of 76 , from a maximum score of 80 . Therefore, the animated video of PowToon can attract students to study chemistry subjects in class $\mathrm{X}$.

The achievement or feasibility of the animated video of PowToon is proven by validation of media and material expert, chemistry teachers' assessment, and students' responses by observing several aspects such as language, material, presentation, audio-visual display, and product characteristics. Based on experts' validation, chemistry teachers' assessment, and students' responses, the product is regarded as feasible and proper media to be used. As learning media, it can help teachers and students in the learning process. This is strengthened by the research conducted by Deliviana (2017) which states that students' responses to the use of PowToon animation video as learning media in science subjects gained a percentage of $89.5 \%$ and it was categorized as feasible media. Moreover, students were more interested and easier to understand the materials presented via video which was designed in an attractive 
and entertaining way.

Based on research conducted by Puspitarini, et al., (2018) the video media based on Powtoon that was developed is feasible to be used as a supporting media in the learning process. This is supported by the results of the study after being tested on 9 small group students getting an average score of 4.32 in the very good category and to 20 large group students getting an average field trial score of 4.19 in the very good category. This is also supported by research conducted by Suprianti (2020) which states that learning activities using Powtoon are not monotonous so that students become more focused on the learning process and students can learn outside of school via the internet. This is also confirmed by research conducted by Rahmawati \& Ramadan (2021) which states that animated video media can make it easier for teachers to convey information to students and can improve students' thinking skills.

\section{Conclusion}

Based on the results and discussion on the development of audiovisual-based PowToon animation video as learning media on chemical bond for tenth grade at SMA N 1 of Serang City, it can be concluded that the animated video is developed by using a 4-D model which is limited to the development stage. In the manufacturing process, the supporting software including Camtasia 2019, Audacity, and Canva are used. The results of media expert's assessment shows that the product obtains an ideal percentage of $96.428 \%$ and it is regarded as very good category. Based on material experts' assessment, it gains an ideal percentage of $84.375 \%$ and it is categorized as very good media. According to three chemistry teachers, an ideal percentage of $98.48 \%$ is obtained for the product and it is considered as very good category. Moreover, in accordance with students' responses, the developed product gets a percentage of $95 \%$. Therefore, this animated video can be used as an alternative learning media in the classroom.

\section{References}

Apriyanti. (2010). Pengaruh metode pembelajaran problem solving terhadap prestasi belajar kimia pokok bahasan ikatan kimia ditinjau dari kemampuan penalaran pada Siswa kelas X SMAN 1 Tawangsari tahun ajaran 2009/2010. Skripsi, tidak diterbitkan, Universitas Sebelas Maret, Solo.

Arianti, K. W., \& Sulisworo, D. (2019). Integrasi Tpack Dalam Pengembangan Multimedia Berbasis Powtoon Pada Pembelajaran Dengan Pokok Bahasan Gelombang Berjalan Dan Gelombang Stasioner Di SMA Muhammadiyah 7 Yogyakarta.
Skripsi, tidak diterbitkan, Univerisitas Ahmad Dahlan, Yogyakarta. Retrieved from http:/ / eprints.uad.ac.id/14808/

Arsyad, A. (2011). Media pembelajaran. Jakarta: Rajawali Pers.

Asmaningrum, H. P. (2018). Pemanfaatan teknologi informasi dan komunikasi oleh guru dalam pembelajaran kimia SMA di Distrik Merauke. Magistra: Jurnal Keguruan dan Ilmu Pendidikan, 5(1), 048-061. https://doi.org/10.35724/magistra.v5i1.722

Awalia, I., Pamungkas, A. S., \& Alamsyah, T. P. (2019). Pengembangan media pembelajaran animasi Powtoon pada mata pelajaran matematika di kelas IV SD. Kreano, Jurnal Matematika KreatifInovatif, 10(1), 49-56. https://doi.org/10.15294/kreano.v10i1.18534

Ayu, D. G., Triwoelandari, R., \& Fahri, M. (2019). Media pembelajaran powtoon terintegrasi nilai-nilai agama pada pembelajaran IPA untuk mengembangkan karakter. Al-Adzka: Jurnal Ilmiah Pendidikan Guru Madrasah Ibtidaiyah, 9(2), 65-74. https://dx.doi.org/10.18592/aladzkapgmi.v9i2.30 $\underline{88}$

Chang, R. (2004). Kimia dasar konsep-konsep inti edisi ketiga jilid 1. Jakarta: Erlangga.

Cholik, C. A. (2017). Pemanfaatan teknologi informasi dan komunikasi untuk meningkatkan pendidikan di Indonesia. Syntax Literate; Jurnal Ilmiah Indonesia, 2(6), 21-30. Retrieved from: http://www.jurnal.syntaxliterate.co.id/index.php Lsyntax literate/article/view/130

Deliviana, E. (2017). Aplikasi powtoon sebagai media pembelajaran: manfaat dan problematikanya. Prosiding Seminar Nasional Dies Natalis ke 56 Universitas Negeri Makassar. Badan Penerbit UNM, Makassar, pp. 1-6.

Farizi, Sulisworo, D., Hasan, M. H., \& Rusdin, M. E. (2019). Pengembangan media animasi untuk mendukung pembelajaran berbasis TPACK dengan powtoon pada materi torsi SMA Kelas XI. Jurnal Penelitian Pembelajaran Fisika, 10(2), 108-113. Retrieved from: http://103.98.176.9/index.php/JP2F/article/view /4017/2754

Latifah, N., \& Lazulva, L. (2020). Desain dan uji coba media pembelajaran berbasis video animasi powtoon sebagai sumber belajar pada materi sistem periodik unsur. Jedchem (Journal Education and Chemistry), 2(1), 26-31. Retrieved from: http://www.ejournal.uniks.ac.id/index.php/JED CHEM/article/view/428

Maharani, I. N., \& Luthfi, S. (2016). Pelatihan membuat media pembelajaran berbasis IT bagi guru-guru SMP Daarul Faalah Cisaat Kabupaten Sukabumi. Surya: Jurnal Seri Pengabdian kepada 
Masyarakat, 2(1), 113-118. Retrieved from: https://jurnal.ummi.ac.id/index.php/JSU/article $/$ view $/ 58$

Maswan \& Muslimin, K. (2017). Teknologi pendidikan, penerapan pembelajaran yang sistematis. Yogyakarta: Pustaka Pelajar.

Meianti, A. (2018). Pengembangan media pembelajaran berbasis audio visual powtoon pada kompetensi dasar menerapkan promosi produk kelas $\mathrm{X}$ Pemasaran SMK Negeri Mojoagung. Jurnal Pendidikan Tata Niaga (JPTN), 6(3). Retrieved from: https://jurnalmahasiswa.unesa.ac.id/index.php/j ptn/article/view/24751

Openhotman, O., Sihaloho, M., \& Isa, I. (2017). Analisis Pemahaman Siswa pada Konsep Ikatan Kimia Menggunakan Tes Paralel. Jambura Journal of Educational Chemistry, 12(2), 149-155.

Pardany, M., \& Dewi, R. (2020). Pengembangan Media Pembelajaran Powtoon Berbasis Pendekatan Saintifik Pada Mata Pelajaran Ekonomi. Jurnal Pendidikan Ekonomi (JUPE), 8(3), 101-108. https://doi.org/10.26740/jupe.v8n3.p101-108

Puspitarini, Y. D., Akhyar, M., \& Djono, D. (2018). Developing powtoon-based video learning media for five grade students of elementary school. In International Conference of Communication Science Research. 165, 173-177. https://dx.doi.org/10.2991/iccsr-18.2018.37

Rahmawati, F., \& Ramadan, Z. H. (2021). Improving High-Level Thinking Skills in Students Through Powtoon-Based Animation Video Media. Journal of Education Technology, 5(4), 654-662. http://dx.doi.org/10.23887/jet.v5i4.41037

Riskiawan, H. Y., Setyohadi, D. P. S., \& Arifianto, A. S. (2016). Pelatihan pengembangan media pembelajaran berbasis multimedia untuk meningkatkan kualitas dan kreativitas guru SMA. J-Dinamika, 1(1). $\quad$ https://doi.org/10.25047/jdinamika.v1i1.134

Sudarsana, I. K., Dewi, N., Sukarmiasih, N. P., Resna, I. K., Arini, I. Restiti, N. W., ... \& Limbong, T. (2018). Paradigma Pedidikan Bermutu Berbasis Teknologi Pendidikan. Bali: Jayapangus Press.

Sugiyono. (2011). Metode penelitian kuantitatif, kualitatif dan RED. Bandung: Afabeta.

Suprianti, G. A. P. (2020). Powtoon Animation Video: A Learning Media for the Sixth Graders. VELES Voices of English Language Education Society, 4(2), 152-162. https://doi.org/10.29408/veles\%20journal.v4i2.25 $\underline{36}$

Swank, R.C (2011), The Educational Function of University Library. Retrieved from: http://www.ideals.illinois.edu/bitestream/handl e/2142/5455/librarytrend.

Widyawati, D. D. (2019). Pengembangan video pembelajaran powtoon pada tema pertumbuhan dan perkembangan makhluk hidup di kelas III SD 2 Wergu Wetan Kudus. Skripsi, tidak diterbitkan, Universitas Negeri Semarang, Semarang. 